\title{
Prevalence of upper gastro intestinal endoscopy findings in endoscopy referred patients at Mosul city, a ten years retrospective study
}

\author{
Makkie A.K. AL-Youzbaki \\ Endoscopy Unit, Department of Medicine, Al-Salam Teaching Hospital, Mosul.
}

(Ann. Coll. Med. Mosul 2010; 36 (1 \& 2): 8-11).

Received: $15^{\text {th }}$ Nov 2009; Accepted: $9^{\text {th }}$ Jun 2010.

\begin{abstract}
Objectives: To analyze the findings of upper $\mathrm{Gl}$ endoscopic examination carried out in order to assess the prevalence of upper $\mathrm{GI}$ disorders in the examined patients.

Design and setting: A retrospective clinical case series study done over a 10 years period from the $1^{\text {st }}$ of October 1998 to the $1^{\text {st }}$ of October 2008, at the Endoscopy Unit of Al Salam Teaching General Hospital during which a total of three thousand seven hundreds and nineteen upper GI endoscopic examinations were performed and analyzed.

Results: The mean age of our patients was 39.8 years and male to female ratio was 1.29:1 (males $56 \%$ and females $44 \%$ ). Out of the total number of patients (3719), a sum of $1322(35.5 \%)$ patients were typed as normal on endoscopic assessment while 2397 (64.5\%) patient were found to retain abnormal findings with the duodenal lesions being the commonest $64 \%$, followed by esophageal one $19 \%$, then gastric lesions $17 \%$. Duodenal ulcer was the most frequently recovered pathology [689 (29\%) patients] followed by duodenitis [483 (20\%) patients], then by gastroesophageal reflux disease [363 (15\%) patients] that is followed by gastritis [312 (13\%) patients].

Conclusions: Upper GI lesions are frequent in Mosul population. The upper GI endoscopy is a valuable mean in the assessment of upper GI symptomatology.
\end{abstract}

Keywords: GI, gastrointestinal.

\section{الخلاصة}

الأهداف: لتحليل نتائج تنظير الجهاز الهضمي العلوي الذي تم إجر اؤه في شعبة التنظير لتقييم أنواع انتشار أمر اض الجهاز الهضمي العلوي للمرضى المحالين. التصميم والاعداد: تم إجر اء در اسة لسلسلة من الحالات السريرية الاسترجاعية والتي امتدت لفترة عثر سنوات ابتداءا من

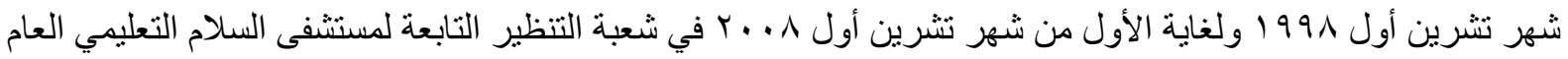

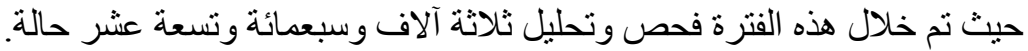

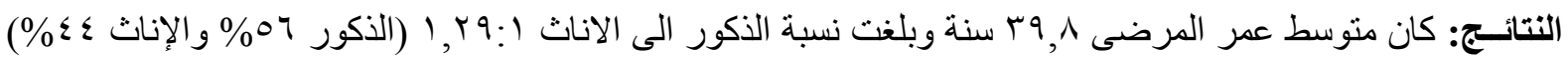

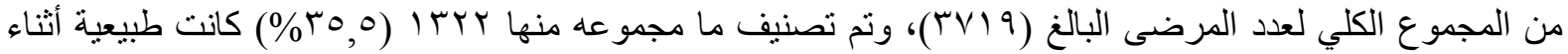

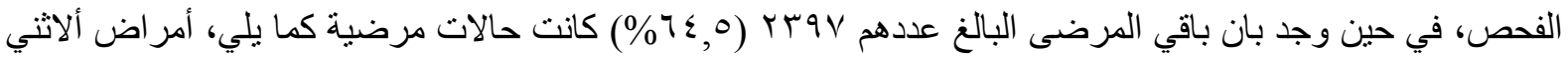

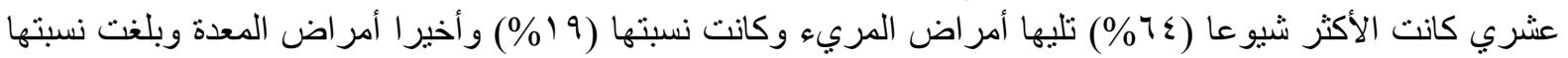

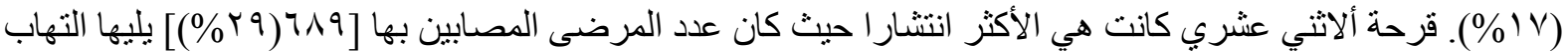

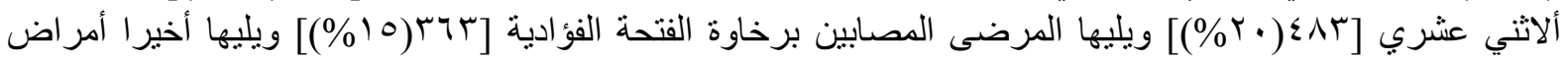

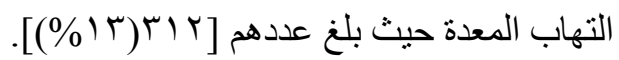




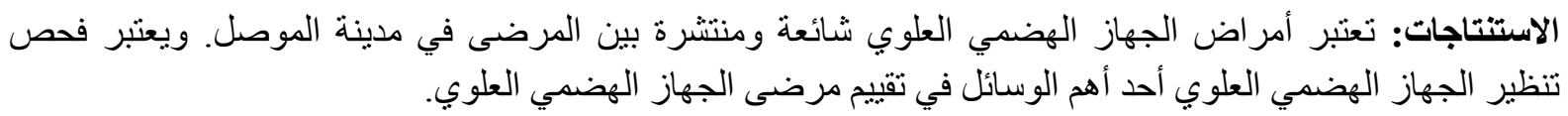

$\mathrm{T}$ he endoscopy of upper GI tract is a safe and easily carried out procedure of both high diagnostic and valuable therapeutic benefits with relatively low incidence of morbidity and low cost.

The era of endoscopy made the information about the prevalence of upper $\mathrm{GI}$ disorders available in various world countries ${ }^{(1-5)}$.

The number of patients attending the endoscopy unit complaining of broad array of upper $\mathrm{GI}$ symptoms is increasing. The upper GI endoscopy that is now performed as the first initial examination instead of contrast studies is carrying a high diagnostic yields in evaluating the explored symptoms ${ }^{(6-8)}$.

\section{The aim of the study}

To analyze the findings of upper $\mathrm{Gl}$ endoscopic examinations within Mosul population.

\section{Patients and methods}

During the period between the $1^{\text {st }}$ of October 1998 and the $1^{\text {st }}$ of October 2008, 3719 patients underwent upper $\mathrm{Gl}$ endoscopic examination and analyzed. Patients were referred from out-patients department, medical wards, surgical wards, and private clinics. The procedure was performed on an overnight fasting patients using lignocaine spray or jelly. Diazepam was rarely used in excited patients in a dose of $5-10 \mathrm{mg}$. Olympus (GIF endoscope, Japan) was used to proceed through the distal second part of duodenum then stomach, with careful assessment of mucosa of upper GI tract was achieved. Biopsies were taken from suspected malignant lesions; antral biopsies for helicobacter pylori detection were performed, also biopsies taken from $2^{\text {nd }}$ part of duodenum for suspected malabsorption. The over all examination was done by one endoscopist, and diagnosis of different pathologies was done according to the American society of gastroenterology criteria. Examination notes were documented and archived properly.
Numbers and percentages plus means were calculated using SPSS software.

\section{Results}

Out of the total number of patients (3719), a sum of 1322 (35\%) patients were typed as normal on endoscopic assessment while 2397 (65\%) patient were found to retain abnormal findings.

The mean age of our patients was 39.8 years and male to female ratio was 1.29:1 (males 56\% and females 44\%). The duodenal lesions were the commonest $64 \%$, followed by esophageal one 19\%, then gastric lesions $17 \%$ table (1). Duodenal ulcer was the most frequently recovered pathology [689(29\%) patients] with a male predominance (M:F= 2.1:1), followed by duodenitis [483(20\%) patients] that also showed male predominance $(\mathrm{M}: \mathrm{F}=1.4: 1)$ table (2), then by gastroesophageal reflux disease [363 (15\%) patients] predominantly among males (M:F= 1.6:1) table (3), followed by gastritis [312 (13\%) patients] that was more predominant among females ( $\mathrm{F}: \mathrm{M}=1.05: 1)$ table (4).

Table (1): Showing the prevalence of regional endoscopic findings, with percentages calculated within the total No. of patients.

\begin{tabular}{|l|c|c|}
\hline \multicolumn{1}{|c|}{ Type of endoscopy } & No. & $\%$ \\
\hline Normal results & 1322 & 35.5 \\
\hline Abnormal results: & 2397 & 64.5 \\
1. Duodenum & 1527 & 41.05 \\
2. Esophagus & 464 & 12.47 \\
3. Stomach & 406 & 10.91 \\
\hline Total No. & 3719 & 100 \\
\hline
\end{tabular}


Table (2): Demonstrates the duodenal array of disorders found on endoscopy.

\begin{tabular}{|l|c|c|c|c|c|}
\hline \multicolumn{1}{|c|}{ Disease } & No. & $\%$ & $\begin{array}{c}\text { Male } \\
\%\end{array}$ & $\begin{array}{c}\text { Female } \\
\%\end{array}$ & $\begin{array}{c}\text { Mean } \\
\text { age }\end{array}$ \\
\hline $\begin{array}{l}\text { Duodenal } \\
\text { ulcer }\end{array}$ & 689 & 45.1 & 67.9 & 32.1 & 37 \\
\hline Duodenitis & 483 & 31.6 & 59.6 & 40.4 & 34 \\
\hline $\begin{array}{l}\text { Celiac } \\
\text { disease }\end{array}$ & 35 & 2.3 & 37.1 & 62.9 & 12 \\
\hline $\begin{array}{l}\text { Bleeding } \\
\text { duodenal } \\
\text { ulcer }\end{array}$ & 50 & 3.3 & 76 & 24 & 41 \\
\hline $\begin{array}{l}\text { Operated } \\
\text { duodenal } \\
\text { ulcer }\end{array}$ & 34 & 2.2 & 73.5 & 26.5 & 45 \\
\hline Deformity & 79 & 5.2 & 64.6 & 35.4 & 38 \\
\hline $\begin{array}{l}\text { Pyloric } \\
\text { obstruction }\end{array}$ & 37 & 2.4 & 75.7 & 24.3 & 45 \\
\hline $\begin{array}{l}\text { Multiple } \\
\text { duodenal } \\
\text { ulcers }\end{array}$ & 53 & 3.4 & 62.3 & 37.7 & 36 \\
\hline $\begin{array}{l}\text { Healed } \\
\text { duodenal } \\
\text { ulcer }\end{array}$ & 67 & 4.3 & 65.7 & 34.3 & 34 \\
\hline \begin{tabular}{l} 
Total No. \\
\hline
\end{tabular} & 1527 & 64 & 64 & \\
\hline
\end{tabular}

Table (3): Shows the esophageal disorders found on endoscopy.

\begin{tabular}{|l|c|c|c|c|c|}
\hline \multicolumn{1}{|c|}{ Disease } & No. & $\%$ & $\begin{array}{c}\text { Male } \\
\%\end{array}$ & $\begin{array}{c}\text { Female } \\
\%\end{array}$ & $\begin{array}{l}\text { Mean } \\
\text { age }\end{array}$ \\
\hline $\begin{array}{l}\text { Gastroesophageal } \\
\text { reflux disease }\end{array}$ & 363 & 78 & 61.7 & 38.3 & 41 \\
\hline Varix & 37 & 8 & 75.6 & 24.4 & 44 \\
\hline Foreign body & 2 & 0.4 & 100 & ----- & 40 \\
\hline Inflammation & 29 & 6.2 & 68 & 32 & 39 \\
\hline Tumors & 11 & 2.4 & 54.5 & 45.5 & 57 \\
\hline Hiatus hernia & 18 & 4.4 & 61 & 39 & 51 \\
\hline $\begin{array}{l}\text { Mallory Weiss } \\
\text { tear }\end{array}$ & 4 & 0.6 & 50 & 50 & 25 \\
\hline Total No. & 464 & 19 & & & \\
\hline
\end{tabular}

Table (4): Demonstrates the gastric lesions found on endoscopic examination.

\begin{tabular}{|l|c|c|c|c|c|}
\hline \multicolumn{1}{|c|}{ Disease } & No. & $\%$ & $\begin{array}{c}\text { Male } \\
\%\end{array}$ & $\begin{array}{c}\text { Female } \\
\%\end{array}$ & $\begin{array}{c}\text { Mean } \\
\text { age }\end{array}$ \\
\hline Gastritis & 312 & 76.8 & 48.7 & 51.3 & 37 \\
\hline Tumors & 72 & 17.7 & 54.2 & 45.8 & 57 \\
\hline Gastric ulcer & 4 & 1 & 75 & 25 & 58 \\
\hline Active Bleeding & 10 & 2.5 & 70 & 30 & 48 \\
\hline $\begin{array}{l}\text { Previous } \\
\text { Operation }\end{array}$ & 5 & 1.2 & 20 & 80 & 53 \\
\hline $\begin{array}{l}\text { Osler weber } \\
\text { rendu }\end{array}$ & 2 & 0.5 & ----- & 100 & 25 \\
\hline Trichobezoar & 1 & 0.2 & ----- & 100 & 25 \\
\hline Total No. & 406 & 17 & & & \\
\hline
\end{tabular}

\section{Discussion}

This study demonstrated that 2397 (65\%) of the examined patients had visible endoscopic findings, the most common lesions observed were duodenal (64\%) followed by esophageal and gastric, (19\%) and (17\%) respectively. The commonest lesion was duodenal ulcer (29\%). This is higher than that found by Sarkis at Basrah $(22.8 \%)^{(9)}$, Sudan $(17 \%)^{(4)}$, and Saudia Arabia $(14 \%)^{(10)}$.

The duodenal ulcer was found to be predominant in males (M:F= 2.1:1) as compared to Sarkis study at Basrah ${ }^{(9)}$ (M:F= $3: 1)$ and a study from Sudan $(M: F=4.5: 1)^{(4)}$.

Benign gastric ulcer was uncommon finding $(0.16 \%)$ when compared to duodenal ulcer (29\%), this was documented also by Sarkis ${ }^{(9)}$ and other studies held at southern Iraq ${ }^{(5)}$, Kuwait ${ }^{(11)}$ and Sudan ${ }^{(4)}$.

\section{Conclusions}

It is concluded that upper GI disorders are prevalent in Mosul population with duodenal ulcer being the commonest pathology followed by duodenitis then by gastoesophageal reflux disease and gastritis respectively.

The upper gastrointestinal endoscopy has a high diagnostic value in investigating upper $\mathrm{Gl}$ symptoms.

\section{Recommendations}

Since that the upper Gl endoscopy is not costly and easily performed, hence we recommend it as the procedure of choice in investigating the upper GI symptomatology. 


\section{References}

1. Fedail S. Araba B, Homeida M, et al. Upper gastrointestinal fibreoptic endoscopy experience in sudan. Lancet 1993; 2:897-899.

2. Al Moagel M, Al Faraji M, Al Mofarreh. Endoscopy of the gastrointestinal tract in Riyadh central hospital. Proceeding of the seventh suadi medicine meeting king faisal university, dammam, 2-6 august 1982.

3. Laajam M, Al Mofleh I, Al Faleh Fz. et al. upper gastrointestinal fibreoptic endoscopy in Suadi Arabia, analysis of 6386 procedures. Quarterly Journal of medicine, new series 1980; 66:21-25.

4. Shoboksh O, Al Sakffizy, Zahrani JY. prevalence of endoscopic findings, Saudi Medical Journal 1994;15: 372-388.

5. Al Hilly $\mathrm{h}$, Alsikafy $\mathrm{H}$, Bakes $\mathrm{S}$, et al. endoscopy in the diagnosis of dyspeptic patients in Basrah region. Medical Journal of Basrah University 1990; 9:93-99.

6. Tedesco FJ. Endoscopy in the evaluation of upper gastrointestinal symptoms indications, expectations and interpretation. J. Clini. Gastro enterol. 1981; 3(2): 67-71.
7. Health and public committee, American College of Physicians, Philadelphia, Pennsylvania, clinical competence in diagnostic OGD. Annals of Internal Medicine 1987; 937-39.

8. The working party of the clinical services committee of the British Society of Gastroenterology. Provision of GI endoscopy and relevant services for district general hospital. GUT.1991; 32:95100.

9. Sarkis K. Upper gastro intestinal endoscopy findings in patients with dyspeptic symptoms in Basrah. Iraqi Journal of Gastro Enterology 2002; 3(1): 45-48.

10. Al karawi M, Ali A, Mohamed A, et al. Upper gastro intestinal endoscopy findings at Riyadh armed forces hospital. Saudi Medical Journal 1999; 20(8): 598-601.

11. Al Nakib B, Al Liddawin. Upper gastro intestinal endoscopy experience in Kuwait analysis of 1019 cases. Gastroenterologic endoscopy. 1981; 23:605-08. 